$88 / 67$

c 
‥ 
PFMILY LIFE

Housing

Jarrell: What year were you born?

Shikuma: 1919.

Jarrell: How many children did your mother have?

Shikuma: She bore seven of us.

Jarreli: How many were boys?

Shikuma: Five boys and two girls.

Jarrell: What was your life like as a child? Can you describe, for instance, what housing was like?

Shikuma: I still remember the type of house we lived in. It was just a single-wall type of structure. One of our jobs, as the newspaper on the walls got older, was to mix the old starch and then paste the newspaper onto the wall to insulate the house. And then of course we had no modern toilet facilities. We had to carry water into the house to wash. I know my mother each night before we'd go to bed would make us wash, but it was just an old tub in the middle of the floor. She'd scrub us and then we'd dip our feet in there and she'd wash our feet and then we'd go to bed.

Jarrell: can you tell. me ... this family house that you lived in, did your father build it?

Shikuma: I recall my dad always saying that at first they had to share homes with other families, you know, that there weren't enough homes for each family. And I think when my older brothers were first born why they were sharing their homes with my dad's uncle. They eventually were able to get an old home of their own. 
$88 / 67 c$ 


University of California, Santa Cruz

Dean E. McHenry Library

HIROSHI SHIKUMA

STRAWBERRY-GROWING IN

THE PAJARO VALLEY

Interviewed and Edited by

Randall Jarrell

Santa Cruz

1986 



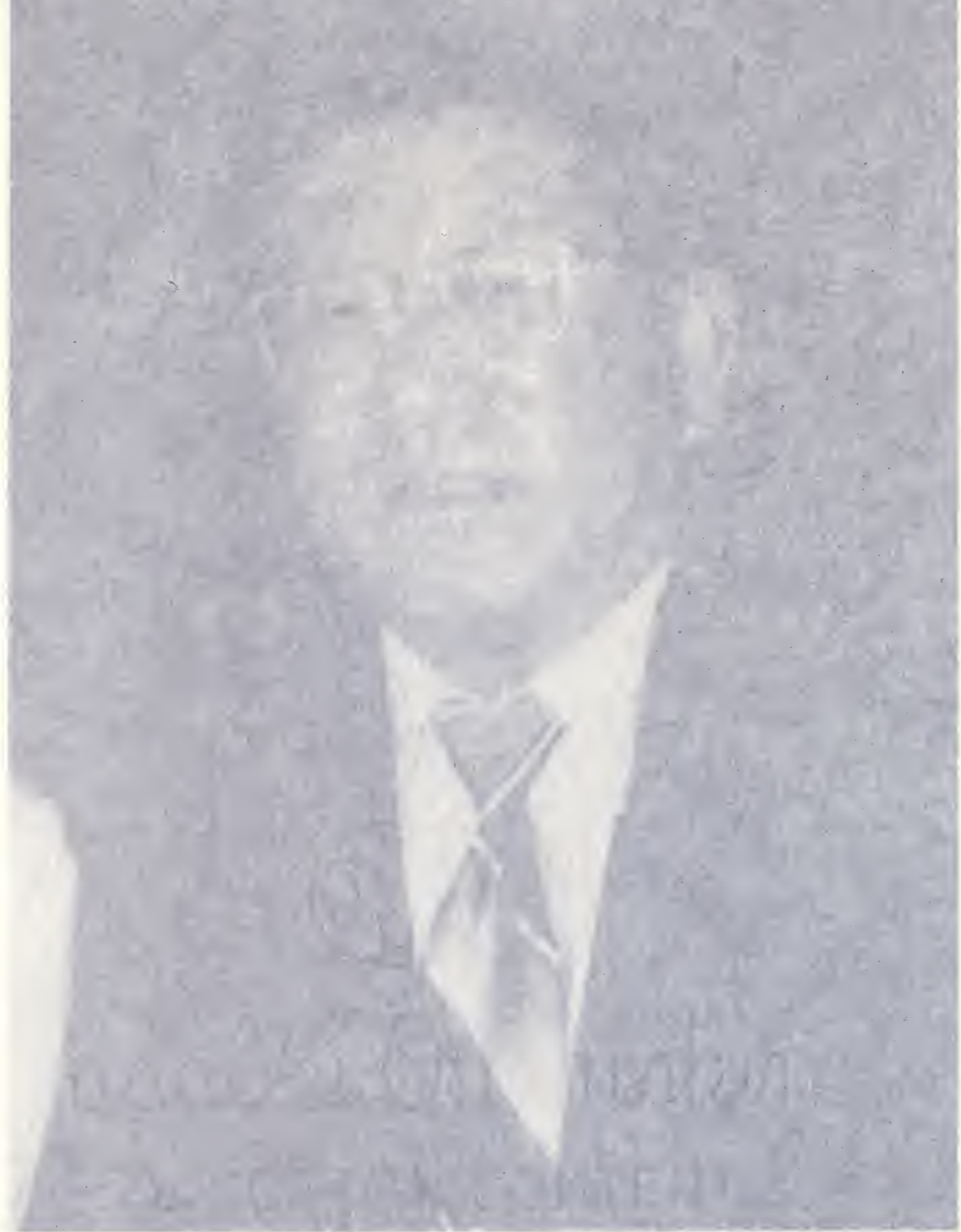

Hiroshi Shikuma 
smuxin' iñoxiH 


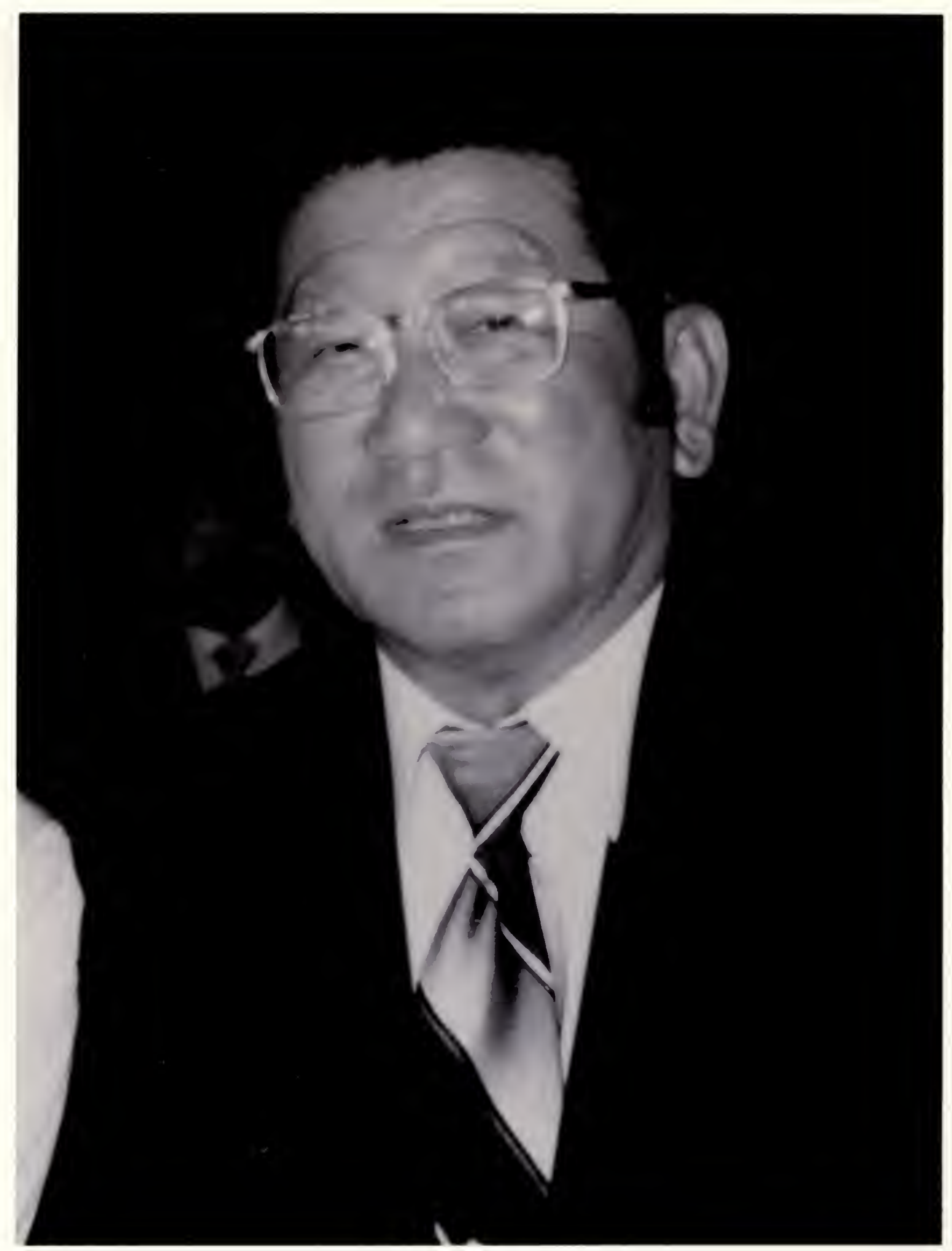



All uses of this manuscript are covered by an agreement between the Regents of the University of California and Hiroshi Shikuma, dated September 13, 1979.

The manuscript is thereby made available for research purposes. All the literary rights in the manuscript, including the right to publish, are reserved to the Dean E. McHenry Library of the university of California, Santa Cruz. No part of the manuscript may be quoted for publication without the permission of the University Librarian of the University of California, Santa Cruz. 


\section{TABIE OF CONTENTS}

ix

].

1

2
INTRODUCTION

FAMILY HISTORY

Unosuke Shikuma -- Arrival from Japan

Unosuke Shikuma -- Farm-Laborer

Haru Maenaga -- Arrival from Jàpan

FAMILY LIFE

Housing

Food and shopping

Religion

Education

Discrimination

Childhood Responsibilities

STRAWBERRIES

Unosuke Shikuma -- Landowner and Grower

Cultivation

Diseases

Mulching

Harvesting

Marketing 


,


STRAWBERRIES [continued]

Marketing -- Cooperatives

34

Marketing - Supply, Demand, and promotion

36

Labor

42

Unions

46

INDEX 



\section{ILLUSTRATIONS}

Hiroshi Shikuma

Hiroshi Shikuma as a young man

Hiroshi Shikuma and S. Akiyoshi

NATURIPE BERRY GROWERS

(Advertising Poster)
Frontispiece

$12 \mathrm{a}$

$25 a$

$31 \mathrm{a}$ 



\section{INTRODUCTION}

The Regional History Project was most fortunate to be able to interview Hiroshi Shikuma, a prominent Nisei strawberry-grower in the Pajaro Valley, as part of its oral history series documenting aspects of the agricultural and ethnic history of southern Santa Cruz County. Mr. Shikuma's father settled in the valley in 1902, and was part of the early group of Issei immigrants who came to California after the Japanese government in 1884 authorized general emigration in response to the persistent demands of the Hawaiian Sugar Planters Association for inexpensive agricultural labor. About the same time, California too was experiencing one of its periodic agricultural labor shortages, engendered by the array of restrictive, anti-Chinese legislative enactments passed during the 1880s and 1890s, which had foreclosed Chinese immigration, the mainstay of the state's agricultural labor force. As Chinese immigration was closed off, Japanese began arriving in record numbers after the turn of the century, filling the vacuum, and going to work in California's fields and orchards.

The consequences of the anti-Chinese legislation were felt in the Pajaro Valley's agricultural economy; there was a labor shortage from the 1890s onwards, until the Japanese began settling there after 1895 -- mostly young, unmarried men from farms and villages in Japan, who began working in the valley's sugar beet fields and apple orchards. They came first in a trickle, with only 19 arriving here in 1900. But by 1910, 689 Japanese had settled in Watsonville and the surrounding area, many living in the Japan Town which had taken shape south of the Pajaro River Bridge, comprised of boarding houses, grocery and general merchandise stores, bath houses, labor clubs, two churches, several photo studios, clothing stores, a laundry, a shoe shop, a Japanese Association, and two medical doctors to serve the fledgling community.

Concurrent with the settlement of the Japanese and their growing importance in the valley's agriculture, was the emergence of a new kind of specialized, horticulturally sophisticated, diversified agriculture. Already the staple crops of wheat, potatoes, and hops were giving way to the apple orchards in economic importance. Yet another phase in the valley's agricultural development was still in its first, experimental stages, as specialty and 

truck crops began to be planted and their chances for success tried out during the first decade of the twentieth century.

In this evolution the Japanese played a pivotal role, cultivating small acreages intensively (as had their counterparts in Japan) in order to cultivate crops with high per-acre yields and returns. One signigicant aspect of this early intensive agriculture was the ability of the Japanese to compete successfully with large vegetable grower-shippers. The immigrants possessed special ingenuity and the capacity for innovation in soil preparation, crop and seed selection, planting, cultivation, mulching, irrigation, and related tasks. They also had their own agricultural style, derived from their cultural legacy, which stressed cooperation and lessened competition among independent Japanese growers in this cohesive ethnic group, as they met and solved common marketing and cultivation problems by working together.

Certainly the development of strawberry cultivation in the Pajaro Valley owes much to the ingenuity, flexibility, and creativity of the Japanese, who in the face of persistent legal, political, social, and economic discrimination, prevailed not only over the elements which face all agriculturists, but created out of their particularly difficult historical situation a unique niche in the state's agriculture as well as singular cooperative solutions to the marketing, transportation, and competitive forces they faced in their struggles.

Over the years here many Japanese have worked in strawberrygrowing, starting out as farm laborers and sharecroppers, and many, such as the shikuma family, have advanced up the agricultural ladder to become independent farm-operators, shipper-growers, and packers. This, despite the barriers imposed by the California anti-Japanese Land Law of 1913, which denied to all persons ineligible for citizenship, the right either to own or to lease agricultural acreage in the state. In 1920, in order to plug the loopholes of the earlier law (which was mostly ineffective), the legislature outlawed the Japanese from leasing agricultural land altogether. Although the pattern of enforcement depended on local officials, and evasions were more often than not ignored, it is nonetheless an indication of the hostility which the Japanese faced, and the situation in which they found themselves as they attempted to make a living. The shikuma family and other lawabiding Japanese residents, could only survive by circumventing the purpose of these land laws, and registering their land in the names of their native-born offspring, since they themselves could not legally own land. 

The most unprecedented and devastating chapter in JapaneseAmerican history in the United States was the action perpetrated against them by President Roosevelt's Executive Order 9066, on February 19, 1942, which resulted in the roundup and internment of some 120,000 Japanese for the duration of the war. The Watsonville Japanese, many of them citizens, were for the most part interned in Poston Camp II in Arizona. It was mandatory for them to sell everything they could not carry with them, which resulted in severe financial losses. When the evacuation order was lifted on January 2, 1945, the Japanese had lost their land, property, livelihoods, and communities, and had to begin life anew. The complex story of the effects of interment on the watsonville Japanese community deserves a detailed history all its own and is touched on only briefly in this interview.

We came to know of the shikuma family's importance in the valley's Japanese Christian community and in the strawberry industry from a number of sources. Eleanor Johnson's The Japanese and Japanese-Americans, published on December 2, 1967, "in commemoration of the Twenty-Fifth Anniversary of the Evacuation of the Japanese from the Pajaro Valley during World War II," indicated that the Shikumas were one of the most important Issei families involved in strawberry-growing. When we consulted the Reverend sumio Koga of Watsonville's Westview Presbyterian Church, for assistance in identifying and selecting an interviewee, he suggested Hiroshi shikuma as a valuable informant.

The Westview Presbyterian Church was originally a Methodist Mission, but was reorganized in 1909 as the Japanese Presbyterian Church, which served the young Japanese farm laborers in the Pajaro valley. It has remained a primary religious and social institution among the Watsonville Japanese since 1898. Hiroshi Shikuma's father, Unosuke Shikuma, was baptized in the church in 1910, and was one of the church's oldest members. He was also one of the valley's pioneering strawberry growers. Arriving in Watsonville in 1902, he joined the first labor club, which numbered about 200 immigrants, established by the valley's first Japanese settler, Sazuki Kimura, to help the young Japanese to find housing and jobs. Unosuke Shikuma's first job was as a farm worker in the onion fields, where he earned a dollar a day, working six days a week. By 1907 he was able to send to Japan for a wife, known to him from his native village. Together they raised a family of seven children, several of whom (including our interviewee) continued in the business started by their father. 

This interview with Hiroshi Shikuma was conducted on March 11 , 1975, at his comfortable ranch-style home on Lakeview Road in Watsonville, across the road from his strawberry fields. The interview focusses on two interrelated subjects: the details of growing up in an Issei family in the Pajaro valley during the 1920 s and 1930s; and the changes in strawberry cultivation and marketing which Mr. Shikuma has witnessed first-hand from his boyhood to the present. Thus the interview parallels the development of a particular specialty crop, strawberries, and the ethnic group singularly identified with its cultivation and marketing as they have evolved since the turn of the century.

In his straightforward narration Shikuma begins with comments on the early history of the shikuma family in California; his father's arrival from Japan and his work as a farm laborer; and the texture of day-to-day family life in the Japanese community, including the details of housing, food preparation, education, religion, and his childhood responsibilities. He includes a discussion of the discrimination faced by Japanese during this period.

The second part of the interview is an historical overview of strawberry cultivation; of Unosuke Shikuma's advancement from laborer to sharecropper to independent grower; the founding of Naturipe Berry Growers, a premier enterprise in the industry; the array of technological, horticultural, and cultivation practices utilized in the pre-World War II era; and the changes in the period after the war, which require of the grower/shipper a high degree of capital investment, sophistication and expertise in today's highly competitive market. Shikuma also addresses the labor problems he has faced over the years in this labor-intensive crop, and the intricacies of timing involved in successfully marketing his berries.

This interview was transcribed verbatim and edited for continuity and clarity. The manuscript was returned to Mr. Shikuma for his appraisal, additions, and corrections, which have been incorporated into the finished manuscript. Mr. and Mrs. Shikuma graciously loaned us the photographs in this volume. Copies of this manuscript are in Bancroft Library, University of California, Berkeley; in Special Collections, University of California, Santa Cruz, and at the Watsonville Public Library. This manuscript is part of a collection of interviews on the history of Santa Cruz county which have been conducted by the Regional History Project. 

The Project is supported administratively by Marion Taylor, head of Collection Planning, and University Librarian Allan J. Dyson.

Randall Jarrell

March 15, 1986

Regional History Project

McHenry Library

University of California, Santa Cruz 

FAMILY HISTORY

Unosuke Shikuma -- Arrival from Japan

Jarrell: When your father came to California, do you know where he came from in Japan?

Slikuma: He's from Yamaguchiken.

Jarrei]: And that's a prefecture?

Shikuma: That's right.

Jarrell: Did he, like so many others that came to the united States, plan to go back to Japan?

Sriikuma: Yes.

Jarrell: What kind of a family did he come from?

Shikuma: Well, from a farm-agricultural family. It was just a small family. His sistex is still living in cortez. She's 88 years old now. He had another brother who passed away.

Jarrell: Kotaro?

Shikuma: No. That was his uncle. I think he's a little more elderly. His brother came here, and that's why my father settled in Watsonville ... that's how he came into Watsonville.

Jarrel1. I see. How long had his brother been here before your father came? Several years maybe?

Shikuna: I think so. 

Jarrel1:

Shikuma :

Shikuma:

Jarre11:

Shikuma:

Jarre11:

Shikuma:

Jarrel1:

Shikuma :

Jarrel1:

Shikuma:

Jarrel1:

Shikuma :

Jarrel1:
And what dja he do? Was he farming of working ...

We11, they were all Earm-laborers here. Those that came fxom Watsonville were farm-laborers.

\section{Unosuke Shikuma - Farm-Laborer}

My father worked here as a laborer. That's how he got into strawberries.

I read that when he first came here he worked in the onion fields.

That's right.

Do you know anything about that?

No, I don't know anything other than he mentioned that he started work in the onion fields. He always mentioned that he helped plant the orchara on Iloionan Road. The orchard is still there. I think it's the o.ld Holohan Orchard.

Apples?

Apples. So he did various types of farm-labor work here.

lle started out as a field hand?

Yes.

Did he ever tell you or anyone jn the family about what kind of working conditions the field rards had in those days?

I know he's talked a lot about it, but you know I wasi't too interested about those things. I am now ... I wish I had listened more closely.

Did your dad speak English? 

Shikuma: No, not when he came. He went to night school ard ... no, a missionary lady came over and tried to teach them [my mother and father] English. And that's how he picked up a few words of English. So as far as doing the shopping for the family and all that, my dad was doing all. of it.

Jarreil: Because he spoke a little English, or ...

Shikuma: Right. He didn't know any of it when he first arrived here.

Jarrell: Do you remember the name of the missionary lady? I think I've heard about her.

Shikuma: Yes. They have a little mission here in town. Gosh ... (laughter) ... I just don't remember those names.

Jarrell: Yes, well, you didn't know her personally?

Shikuma: No, no. I know my brother kenji was very familiar with all this.

Jarrell: I see.

Haru Maenaga -- Arrival from Japan

Jarrell: Do you know anything about your mother's courtship. When she came over here in $1907 \ldots$

Snikuma: No.

Jarrell: Was she from the same prefecture as your father?

Shikuraa: Yes.

Jarrell: Did the families know each other then?

Shikuma: yes. Well the fact you know that families were related ... it's just one of those things that's all arranged within the family. 

Jarrell: So she wasn't a picture bricie ... because the families knew each other and knew their children?

Shikuma: That's right.

Jarrell: And when she came here then I guess she arrived in San Francisco?

Shikuma: No, wait a minute. I think she arrived in seattle.

Jarrell: Seattle. Did she speak English?

Shikurna: She spoke no English.

Jarrell: How did she get down to Watsonville?

Shikuma: Well I think they came as a group. I think there was someone that kind of chaperoned the group who understood a little English and how to get them here to Watsonville.

Jarrell: Has your mother ever told you or anyone in the family about ... was she homesick? Did she feel strange being here and not speaking the language?

Shikuma: Yes, she experienced all that. I think she was very homesick when she got here because everything was so strange and no one understood the language. The only comfort that they had was that there was a group of them, you know.

Jarrell: They at least had that common family life.

Shikuma: Yes. They had others to talk with within their own group. 

FEMILY LIEE

Housing

Jarrell: What year were you born?

Shikuma: 1919.

Jarrell: How many children did your mother have?

Shikuma: She bore seven of us.

Jarxeli: Hiow many were boys?

Shikuma: Five boys and two girls.

Jarrell: What was your life like as a child? Can you describe, for instance, what housing was like?

Shikuma: I still remember the type of house we lived in. It was just a single-wall type of structure. One of our jobs, as the newspaper on the walls got older, was to mix the old starch and then paste the newspaper onto the wall to insulate the house. And then of course we had no modern toilet facilities. We had to carry water into the house to wash. I know my mother each night before we'd go to bed would make us wash, but it was just an old tub in the midale of the flcor. She'd scrub us and then we'd dip our feet in there and she'd wash our feet and then we'd go to bed.

Jarrell: can you tell me ... this family house that you lived in, did your father build it?

Shikuma: I recall my dad always saying that at first they had to share homes with other families, you know, that there weren't enough homes for each family. And I think when my older brothers were first born why they were sharing their homes with my dad's uncle. they eventually were able to get an old home of their own. 
$+$ 
Food and Shopping

Jarrel1: During your growing-up years, what kind of food did you eat? What did your mother prepare?

Shikuma: Japanese style rice; rice was our basic food. We also had fish and vegetables, but not too much meat.

Jarrell: Did you always have a family vegetable garden?

Shikuma: Yes. They always raised the Japanese vegetables: daikon and nappa and things like that.

Jarrell: Where did you get the rice?

Shikuma: In town.

Jarrell: Where did your mother or your father shop? Later I suppose your mother did the shopping.

Shikuma: Well, thore were Japanese merchants in town. We could get all the Japanese food from them. And then once a week, these Japanese people [in my time, they were able to have old cars] would come with what amounts to an old panel or pickup. They would come to peddle these Japanese food iterns.

Jarrell: I see. I never knew that was practiced around here.

Shikuma: Fish peddlers would come weekly, too.

Jarrell: Japanese peddlerś?

Shikuna: There was one Japanese fish peddler, and then there was an Italian peddler that would call on the Japanese.

Jarrell: Would this be someone from Moss Landing or Monterey? Do you happen to remember?

Shikuma: 130. I don't know just where the fish was coming from. I think it was from Moss Landing and from out of Monterey. 
Religion

Jarrell: Was your father a Christian in Japan?

Shikuma: No. They were all Buddhists. They were converted here, through the missionaries.

Jarrell: Once he became a christian, was religion an important part of your father's life?

Shikuma: To my dad, yes, very important. He took his religion, Christianity, very seriously.

Jarrell: Was your mother also converted?

Shikuma: Yes.

Jarrell: So you grew up in a household then ... for instance the children were baptized?

Shikuma: Yes.

Jarrell: Did the church play an important part in the social life of the community that your family was a part of?

Shikuma: Very much so, I think. My social life and even athletics, when I was a child, revolved around the church. The basketball teams we had were centered around the church ... or within our own church group. I don't know ... it seems like those that were with the Buddhist faith and those of us in the Christian faith were kind of apart. And I know my life, unlike my children's lives now, was centered around the church. All our socials and everything revolved around the church.

\section{Education}

Jarrell: Did you speak English?

Shikuma: I spoke no English until I actually started school. 
Jarrell: Which was when you were five or six?

Shikuma: I started at age five in the Roach district.

Jarrell: And that was just a regular public school?

Shikuma: Yes, a regular public school.

Jarrell: And you say this was the Roach district?

Shikuma: That's where I started school. My first year of grammar school was there. When I started my second year, we [using my brother's name] purchased property in Corralitos, so we moved there and I finished my grammar schooi years in Corralitos. Later I went to Watsonville High School by bus.

Jarrell: You started school about 1924?

Shikuma: 1925 I think. I was born 19th December, very close to 1920 .

Jarrell: Oh. I see. Do you recall if there were many Japanese chilaren?

Shikuma: Quite a few, quite a few, because the Japanese kind of stayed together, you know. We had to move with the strawberries because, unlike now, we had to seek new soil. At that time, when you grew a crop of strawberries, you never replanted back onto the same soil. So the community would kind of move from one area to another.

Jarrell: What kind of distance would be involved in moving?

Shikuma: well we were pretty close. I can recall as a child that the little group that I was with was within a guarter mile of the next group. Many of us were together. There'd be two or three families all within a quarter mile of us, and we would move kind of like a group. We'd rent or get a piece of ground ... rny dad was unable to rent ground, but a lot of it 
. 
was rented through his son's name or my brother's name.

Jarrell: Now this had to do with the alien land rights?

Shikuma: That's right.

Jarrell: So that your father himself ...

Shikuma: Was unable to lease, rent, or to buy land.

Jarrell: So he used whose name then?

Shikuma: I think at first there was an older Nisei who was born here who was able to rent or lease a parcel of ground; the whole group would farm it. When my brother became old enough, why then he was able to lease ground. That's when we finally purchased our first property in corralitos. It was under my brother's name.

Jarrell: I see.

Discrimination

Jarrell: Did your father ever talk to you or anyone in your family about any difficulties [arising] from discrimination or prejudice in his business life?

Shikuma: Well, my dad was ... I know he experienced discrimination and all that, but as far as I can remember he never talked to us [the children] very much [about] the hardships that he was going through because he was a Japanese. The only hardship that I knew [about] without [his] telling me was that he was unable to purchase or lease land. I kind of became aware of that and somehow I just felt that it was because we were of a different race. But he never expressed any bitter feelings [over] experiencing hardship because of it. He just took it as one of the challenges of life.

Jarrell: He sort of kept it to himself. 
Shikuma: Yes. Of course as we grew up, I began to feel the prejudices and the discriminations myself. Pcople would yell "Jap" at us, or things like that. But then, I don't know, I never felt bitter about it. I didn't like it, but then I thought well it's just [an] unfortunate thing that I'm of [the] Japanese race, of Japanese ancestry.

Jarrell: Did you feel angry when you experienced this as a child, or in high school, or growing up?

Shikuma:

No ... this is just my own personal feeling, but I never really felt angry about it. I just kind of accepted it. To me, it was kind of a challenge that I was going to have to overcome :- this kind of discrimination. I didn't know how to overcome it at that time. Of course when I grew older and got on my own. I felt that. I just had to make the best of it and try to make as much money as I could and succeed as much as I could in climbing, so that at least I'd be respected for what I am, and what I possess.

Jarrell: Yes. You wanted to make good.

Shikuma:

This is still the kind of feeling I have now. others may have felt differently. I think some did, you know, especially when we went into the relocation center.* I didn't feel bitter that we were placed in a relocation center. Like I said, I figured that I just happened to be of the Japanese race and we were at war and my ancestors were at war and unfortunately because of my race, I was being put

*Eà. Note:

The Japanese attack on Pearl Harbor, December 7, 1941, aroused fears among government officials about the loyalty of JapaneseAmericans, most of whom lived on or near the West coast. Executive Order 9066, signed by President Roosevelt on February 19, 1942, ordered that Japanese-Americans, both aliens and citizens, be evacuated and settled inland. Executive order 9102 of March 18th, created the War Relocation Authority, which established ten relocation camps in Arizona, California, Idaho, Wyoming, Colorado, and Arkansas in which over 110,000 JapaneseAmericans were detained for the duration of the war. 

into this position. There were a few, I guess, that felt a little differently than I did. Evidently so, because when they came out with a questionnaire in camp on this "yes and no" business, and I put "yes", that I would be willing to serve and I was still loyal to the country, I guess there was a few that said "no".

Jarrell: This was a survey before ...

Shikuma: $\quad .$. while we were in the relocation center.

Jarrell: I see. It asked if you would serve in the armed forces?

Shikuma: Yes, that was the questionnaire that we were given by the United States government.

\section{Childhood Responsibilities}

Jarrell: What were your responsibilities as a child to your family? What were you expected to do and to take care of?

Shikuma: Well whenever we had time, we'd help with the strawberries. Of course when I started to grow up, my dad began to have sharecroppers and not too many berries of our own, so $r$ didn't have to go out in the strawberry field. But then I would help the sharecroppers. I know that when I got old enough, I helped my dad collect and pick up the strawberries from the sharecroppers and load them onto the trucks to haul to the market.

Jarrell: To the SP? [Southern Pacific]

Shikuma: Yes and also to what was then referred to as clark Brothers. They had a trucking firm here in town that brought the strawberries into the San Francisco market. For the Los Angeles market we'd have to bring the strawberries down to the SP depot right 

here on Pajaro.

Jarrell: So in those days, your family helped your dad?

Shikuma: Yes.

Jarrell: And he would also have other families sharecropping?

Shikuma: Yes.

Jarrell: When the families would work together... let's say they would have a piece of property or acreage that was leased ... when you all worked together, would the mothers and the children also work?

Shikuma: Yes.

Jarrell: Were you taken out of school to do this?

Shikuma: No, just anytime we could help, why we helped.

Jarrell: So everyone was cooperating. How was the determination made for payment? Whom did you sell the strawberries to?

Shikuma: Well, each one farmed his own parcel.

Jarrell: And how big of a parcel would that be?

Shikuma: Usually it was very small because so much of it was done by hand ... it was two acres, three acres of land.

Jarrell: At the most?

Shikuma: Yes, a large parcel would be three acres.

Jarrell: And each family unit would be responsible then for that part of it?

Shikuma: That's right. We were independent of the others as far as I can remember. 



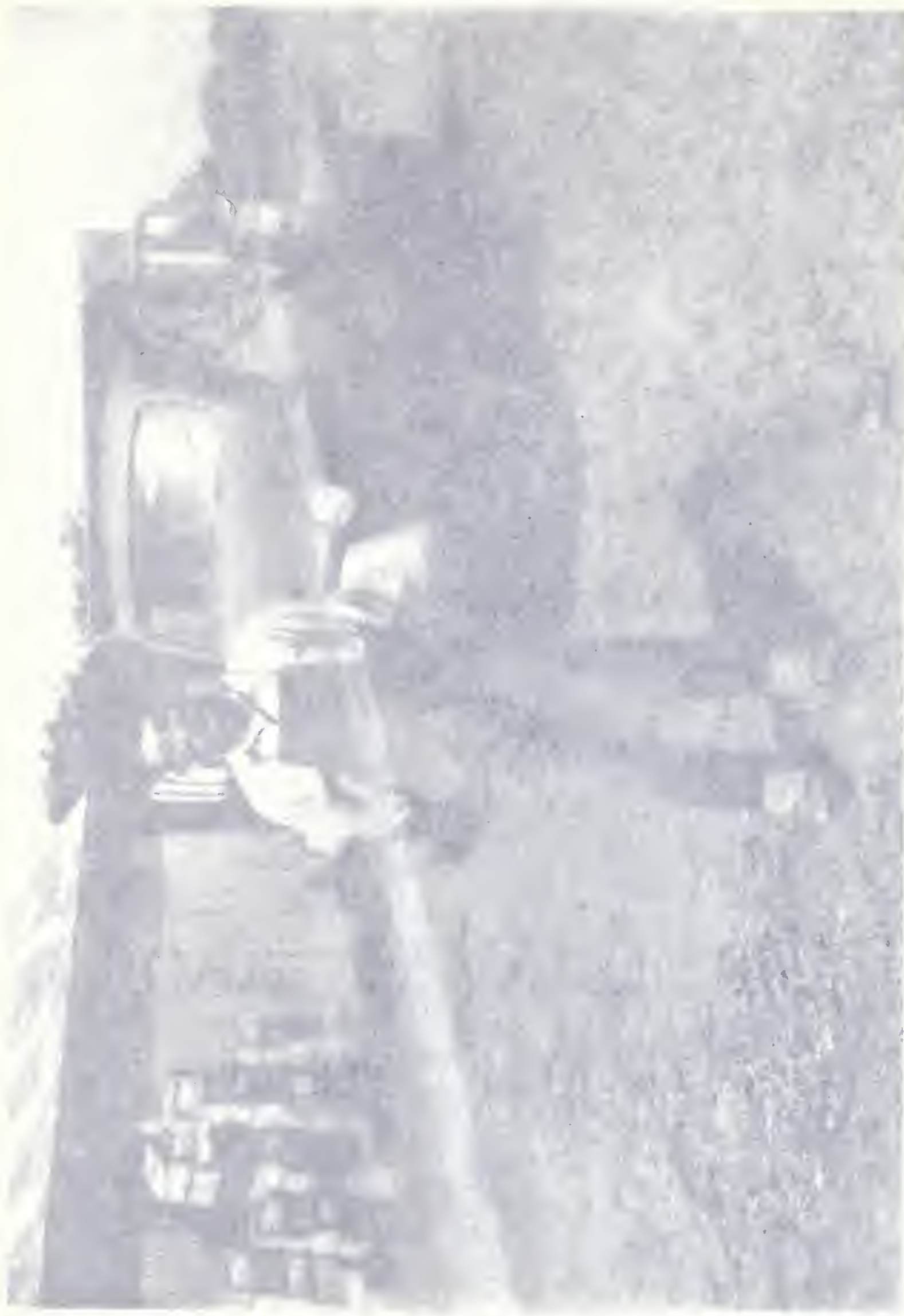

ב 
GSI

20
0
0
0
0
0
0
0
0
0
0
0
0
0
3
5
5
5
0
5
5
0
0
0
$k$
5
0 


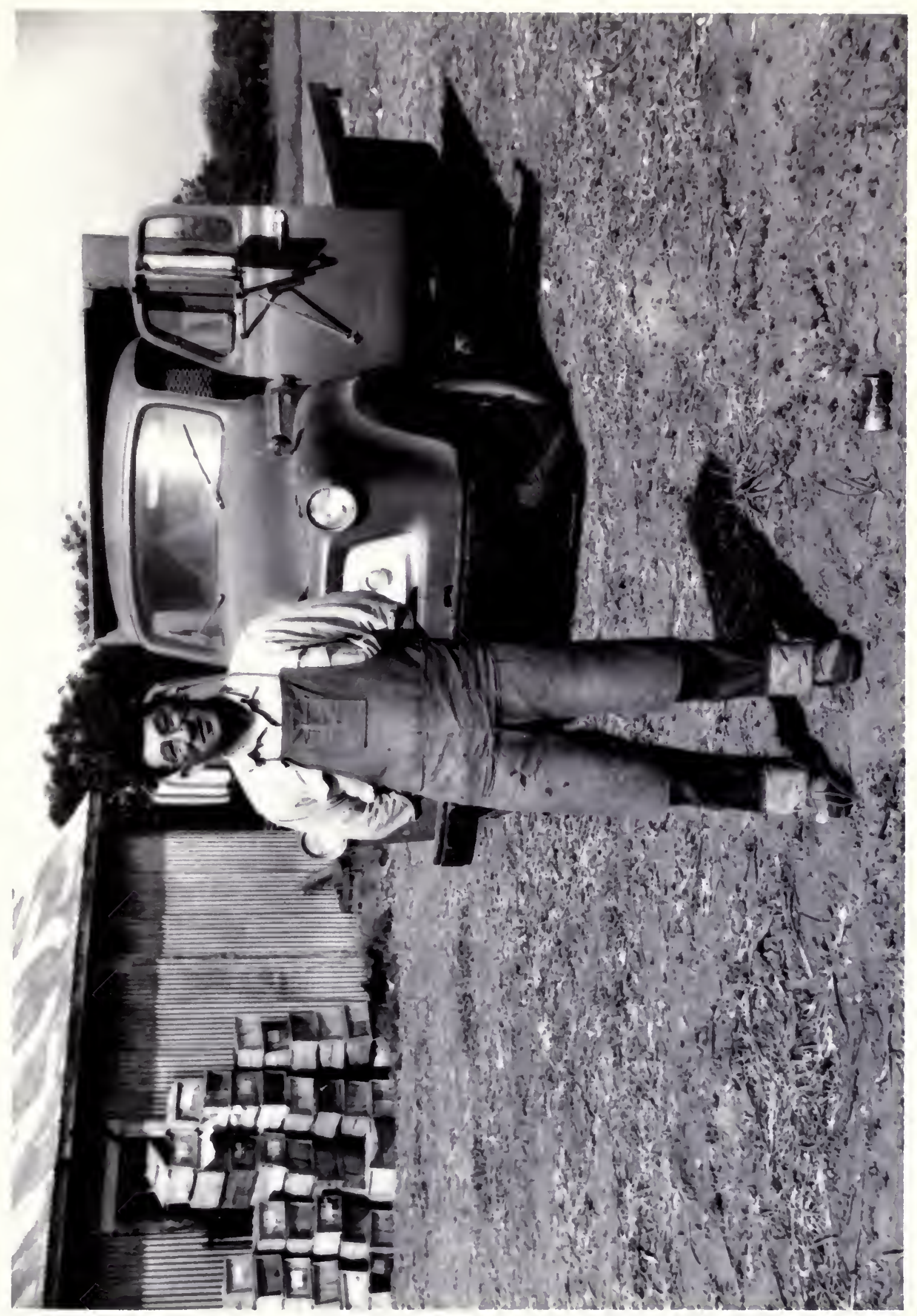





\section{STRAWBERRIES}

\section{Unosuke Shikuma -- Landowner and Grower}

Jarrell: When your father purchased, through your brother's name, his first parcel of land out in Corralitos, he had sharecroppers who worked on the land?

Shikuna: That's right.

Jarrell: Were they Japanese people?

Shikuma: Japanese.

Jarrell: Who had just come over from Japan?

Shikuma: Nio. They were families that had been here almost before my parents, or my father. Many came after my dad's time too. But they were... let's see... as far as I can remember there was the Kiyotoki family ...

Jarrell: Kiyotoki?

Shikuma: Yes. They were sharecroppers. So were the Hirokawa and Iotsishitas and Nakamura. Some were younger thar my dad, but some were equivalent in age to my did. But those who didn't have sons old enough to purchase a place, or who didn't want a place of their own, why they sharecropped for my dad.

Jarrell: Find he would take what percentage of the crop, do you know?

Shikunia: Usually ... as far as I can remember ... it was a $50 / 50$ thing. My dad would provide the land and the nlants ard the tools and work the ground ... they would provide the labor. And then when the berries were harvested and marketed, why then we would divide the income. He would get families to sharecrop for him. The chilaren of our sharecroppers, I know they picked strawberries from ... oh, sometimes, 5:00, 5:30 

in the morning until they had to leave for school. This way they worked a few hours before they left for school. Then they'd come home from school and pick some more berries until quitting time.

Jarrell: Now I read that your father also was a sharecropper himself in the early years.

Shikuma: I think he was. But that was before I was even born.

Jarrell: I see. I just wondered if you could tell me about that?

Shikuma: I don't recall too much of it. My brother could probably tell you more, 'cause Mać is thirteen years older than I.

Jarrell: I've read that when your father first leased his land and became an independent grower, that it was very difficult in those days, especially for a Japariese, to acquire the capical necessary to even buy the land ... and also to buy the other furnishings that would be necessary. Do you know anything about how he got the money?

Shikuma: What I recall is that he always spoke about JMB and Bonora. He went to the commission ...

Jarrell: JMB?

Shikuma: Jacobs, Nalcom, Burke... I don't think they're in business any longer. Burke had numerous commission houses where my father would commit his berries and then they would advance him the money.

Jarrell: Before the crop cane in?

Shikuma: Yes. There were commission houses in San Francisco and Oakland.

Jarrell: So he went to them? 

Shikuma: Yes.

Jarrell: And they furnished him with the money for his first venture as an independent grower?

Shikuma: Yes.

\section{Cultivation}

Tarrell: From the time that your father grew berries and now that you are growing berries, what major changes in the growing techniques have occurred in the ways that the plants are actually laid out or taken care of?

Shikuma: Well, when my dad farmed berries, he would use very few plants from the nursery. These plants would runner and then the workers would go by hand and place each runner. Then they'd trim off the runners that they didn't need and they'd fill in their planting beds that way. Now we just use the plants right from the nursery to fill in our needs. Whenever they rumner, why we trim the plants and discard all the runners; we never utilize them.

Jarrell: Now why do you do this? Is it because of the tractors?

Shikuma: That's right, yes. Instead of two rows on a bed, which is more expensive because of the higher cost of labor ... we plant a single bed. We try to utilize the labor more inexpensively, so they pick more crates per hour. We go single rows in a bed, you know, so the pickers won't waste any time searching for fruit. The fruit's more exposed. But this is subject to change again. You've probably heard of drip irrigation. Now with this drip irrigation, there are a few growers going to a real wide bed. They're putting four rows to a bed.

Jarrell: I see. 

Shikuma:

Jarrell:

Shikuma:

Jarrell:

Shikuma:

Jarrel1:

Shikuma:

Jarrell:

Shikuma: Roughly.

Jarre11: Doesn't a more intense irrigation result from having the plants closely placed like this?

Shifuma: Yes. The only way you can get that is with the drip irrigation. 



\section{Diseases}

Jarrell: Now you were telling me earlier that berries, grown when you were a youngster, were grown in a particular ficld for a particular crop and then you'd move on. Why was this so?

Shikuma: It was because of the disease factor. Fungus and different diseases would attack the strawberries. Mainly, it was because of verticillium wilt.

Jarrell: Verticillium wilt?

Shikuma: It's a fungus.

Jarrell: In those days you knew there was some kind of a disease?

Shikuma: Yes, if you replanted the same ficld. I don't think they really knew at that time, but they knew that if you repianted back onto the same soil you would never have the same result as going into a virgin soil.

Jarrell: And then it would attack the new plants in the virgin soil, and so you'd keep going.

Shikuma: That's correct.

Jarrell: Now when did this change?

Shikuma: This changed after I went into strawberry growing myself in 1949. I would say that we went into fumigation with chloropicrin and methyl bromides around 1957 or '58. I don't really recall but it was around that time when this type of fumigation became available.

Jarrell: Before 1957, would you use the same plants every year and just transfer them?

Shikuma: No.

Jarrell: you destroyed them? 

Shikuma: Yes. We'd buy new plants from the nursery.

Jarrell: I see. Was that expensive per acre?

Shikuma: At that time, as I recall, my cost was about \$12 per 1000. We would plant oh, from 24,000 plants to 26,000 plants to an acre. It was an expensive item. At that time, it was the most expensive item.

Jarrell: I was reading the article your brother kenji wrote, * the article on strawberries. He says they used to use the same plants year after year.

Shikuma: Well once you planted it, you would keep the plant for about four years.

Jarrel1: I see. And then he said the practice changed and they started using new plants. each season.

Shikuma: Right. That's what we're doing now. Even after fumigation, we were going two or three ycars without replanting. Now there's still a little of that left, but the majority of us are converting to almost an annual planting. Of course that's because of the quality factor and the labor factor and all that.

Jarrell: What are some of the other diseases or problems particular to strawberries?

Shikuma: Well our main insect problem is the two-spotted mite. During the last $\mathrm{E} \in \mathrm{w}$ years the cyclamen has been reoccurring. It was a very major problem before the fumigation... before we started to go into this annual and short growing season. Now that some of the cyclamen are reoccurring in our second-year plantjngs, especially if the Driscoll*t people keep a little bit second year ... University, what we

the Seventy-Fifth Anniversary of Mission Work in Watsonville, California, October 28, 1973. (Westvies Urited Presbyterian Church, Watsonville, California). This memorial pamphlet contains a reminiscence by Kenji Shikuma.

**Driscoll Strawberry Associates, Inc. of Watsonville. 

Jarrell: Why?

Shikuma: It's outlawed by the Food and Drug Administration. Thiodan isn't as effective as endrin. Of course the farmers ... we've been kind of neglectful because the cyclamen wasn't too much of a problem for a while and then I think we became careless about it. We didn't really give a thorough spray for it after harvesting season was over in the fall. So now the cyclamen is reoccurring. I think a few of the farmers are quite concerned about it again. I saw it last fall quite heavily in my field ... the first time so heavy.

Jarrel1: So what did you do?

Shikuma: Well, this spring I gave it a good dousing with this Thiodan. We can only use it for three weeks prior to harvest, so before harvest, if I can get in another spraying again, I am going to give it another dousing. Then I'll hope for the best.

Jarrell: The varieties of the strawberry that the University has produced arc, I suppose, fairly hardy and invulnerable to a lot of problems. But are they still, as crops go, a fairly delicate or sensitive species?

Shikuma: Yes they are. Rain is a problem. They can't stand much of the rain. We thought this new fungicide, Benlate, was going to help us. But now it looks to me like there's a little resistance to Benlate.

Jarreil: Now what does Benlate do? 

Shikuma: It inhibits mold after the rain.

Jarrell: It protects against dampness. I see.

Shikuma: Yes. But, I don't know, we have our doubts about how effective it is. So rain is a major problem. The two-spotted mite is a tough one to control. of course we have Omite and Plictran to deal with this, but regardless, we're restricted to two or three applications a season. We can't, just because the mites are there, use it weekly anymore. If we use it now, we're going to have to space ourselves on when we can use it again. This new product, Plictran, just became available last year. We can't dust it; we can only spray it as a liquid. And when you have to liquid spray, then you're going to have to get a commercial liquid sprayer in, and if your fruit is hanging heavy, why you're going to get a little damage to it from the spray.

Jarrell: Why?

Shikuma: Because the tires go over the plants. You could hose it, but that requires a lot of labor. If you do that, you're restricted to a certain number of applications. But I think Plictran being the newer of the two materials will probably be more effective, but only as a spray.

Jarrell: You're not allowed to dust the plants?

Shikuma: No.

Jarreil: Isn't that how it's usually done?

Shikuma: Well, we can't use airplanes with the dust anymore.

Jarrell: How do you apply it then?

Shikuma: I apply it with my tractor. I have a duster with the rractor. On the small patches on the side hills where they can't use these tractors, they have sprayed using 

a little backpack that sprays dust. With the regulations we have now, I don't know if we're going to be able to hack it.

Jarrell: In the old days when your father started, you just kept moving. Is that correct?

Shikuma: Yes.

Jarrell: Was this your way of dealing with the pests and the mites and the funguses?

Shikuma: Yes.

Jarrell: There were no remedies in terms of chemicals?

Shikuma: No. But you know, my father's strawberry field would come out lush in the spring and produce a crop and then it would turn all. yellow. My dad would give it fertilizer and give it a lot of water and hope that it would come back in the fall.

Jarrell: What kind of fertilizer did he use?

Shikuma: I don't recall just what kind of a mixture they used. I kind of imagine that there probably was a lot of nitrogen in it. I don't think the fertilizer was quite as sophisticated as it is today.

Jarrell: Or as specific for the crop.

Shikuma: Right.

Jarrell: So he used to water and fertilize when the plants turned yellow?

Shikuma: Yes. They hoped that it would come back in the fall. And I think those fields that did come back were probably helped by the predators that would probably come in and eat the insects. We still have predators on two ... the cyciamen mite and on the two-spotted mites. If you have an infestation of two-spotted 

mites, then predators move in. Now that we don't go in with these sprays like parathion that kill the predators, they are coming in a little more. Omite and Plictran aren't harmful to the predators. So in my program I watch my ficld and if I sce predators in there and I think they can get ahold of it, I withhold my spraying program. I don't spray quite as much and just let the predators kind of try to handle the thing. I think that's what was happening in the olden days. But they were losing a crop on account of that ... waiting for the predators to come in. We're able to harvest right through because of our spray program.

Jarrell: Well if you had to judge or evaluate the old style which was a game of wait and see .... there was nothing really you could do except to fertilize, water, and hope for the best?

Shikuma: Yes.

Jarrell: Today with all of these restrictions on the kinds of pesticide that you can use, you still think that these restrictions are going to seriously challenge the success of your crops ... more than the results you obtained with just fertilizer. Is that correct?

Shikuma: Well, I think with the two-spots we can use the Omite and the Plictran and be successful. There aren't too many restrictions other than the time intervals involved. Plictran seems to carry over for a longer period of time. 'I don't think that we're hurt too bad with it. Now the cyclamen mite... I don't know how we're going to handle it. It's a really serious problem. The Driscoll people have their entomologists and all tineir specialists trying a little bit of what we were trying in the old times. We used to put mulch on the plants and shoot methyl-bromide gas in the soil to try to eliminate the cyclamen mite. They're experimenting this winter on different plots. It's an expensive process to put a plastic mulch over the plants. We tried mulching a little bit just 

before our cultural practices changed and endrin and Thiodan became available. That's an expensive process too.

\section{Mulching}

Jarrell: Now I noticed down on Lakeview Road when I was driving up here, that there was a field with this plastic mulch on it.

Shikuma: That's mine.

Jarrell: Oh, that's yours?

Shikuma: Yes.

Jarrell: Now those were just single rows.

Shikuma: Single rows, yes.

Jarrell: Isn't that plastic pretty expensive?

Shikuma: The plastic this year ... this particular plastic that I'm placing now is $71-74 \xi$ a pound against $31-34$ c last year. The cost has doubled.

Jarrell: It's made of oil, I guess.

Shikuma: Right. It's an oil byproduct. If you looked closely, you would have seen a plot without plastic which I'm just kind of experimenting with. I'm comparing the two.

Jarrell: In your father's day, I suppose they just used natural mulch or hay.

Shikuma: He didn't mulch at all.

Jarrell: How would they conserve their moisture? Didn't they worry about that? 

Shikuma:

Well no, I guess they didn't. I don't think this plastic is conscrving moisture. It's the use of the plastic that has changed. We used it for weed control, or mold control. But now all that has changed.

\section{Harvesting}

Shikuma: When we first went to plastic, it was mainly because we were trying to get our berries into the market a week to two weeks earlier. We don't want the berries to come in early because Anaheim or Orange county is already in and we can't ... we'd be bumping heads with them. Then ventura county comes in. So now we're really trying to come into the May and June markets.

Jarre11: When are the strawberries harvested here?

Shikuma: I think we will start after the middle of April. So this plastic is really purchased as we try to come into earlier markets. I kind of delay laying the plastic for as long as I can instead of trying to lay my plastic early as before.

Jarre11: You want to boost your time ahead so that you're later in the season?

Shikuma: Yes. I'm trying to lay the plastic as late as I can.

Jarre11: So that you won't be bumping heads with those other countics?

Shikuma: That's right. I'm using the plastic now to get the cleaner fruit and reduce the mold on my fruit in case of a late rain. But maybe ... that doesn't mean too much ... I mean the Driscoll people aren't ising piastic because their fruit comes in mainly during the latter part of May. Their crop will come in early but then their main production will 

be in late May and into June and partly into July. So I'm just experimenting now with lots of plastic to see how much later the fruit is going to come in with the plastic than the one without the plastic. Also I want to assess the difference in damage in case we do get a late rain. I also want to know the difference in the quality of food and all that. I want to see for myself.

Jarrell: Would you say that the strawberry is still a vital crop for the Pajaro valley?

Shikuma: I believe it is, yes. Once the Pajaro valley comes into production, the other areas no longer can compete with us. Fortunately, Orange County is in production now and when we come into production, why then they're pushed off of the market. They no longer can compete with us quality-wise or price-wise. So they either shift to the freezer or they discontinue production. Their season is terminated. And then of course after orange County, Ventura County comes into production. We kind of bump heads there for a period. Then of course we can keep going, but they'll probably go to the freezer or they try to stay in the market a little bit longer. But that is the only time that we have for selling. We still have to depend a little bit on the processed berries, too. Ventura produces quite a bit of processed berries, too. Frozen berries kind of set the base for our fresh berry market and naturaliy they're freezing berries when they can't compete with us on the fresh market. This naturally sets the amount of berries that I can put into storage.

Jarrell: Would you say that the berries in the Pajaro Valley area are primarily for the fresh market?

Shikuma: Yes.

Jarrell: Is there some kind of a differential in terms of the profits you make between the berries that are processed, frozen, canned, as opposed to fresh berries? You sell 


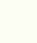




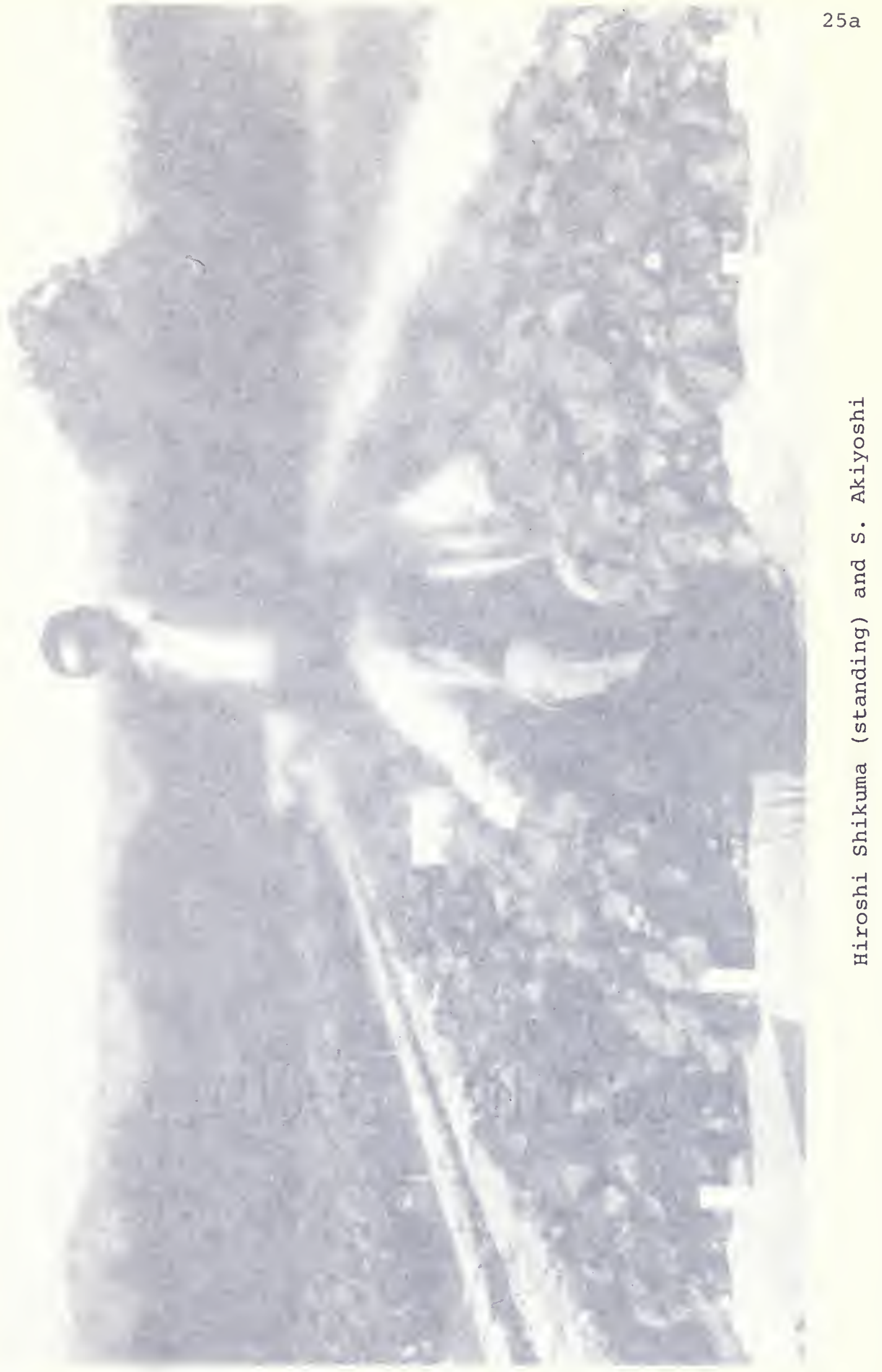


62S

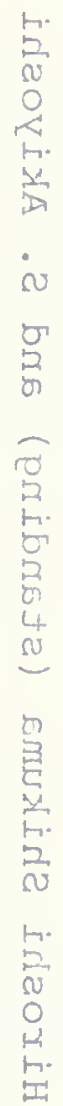



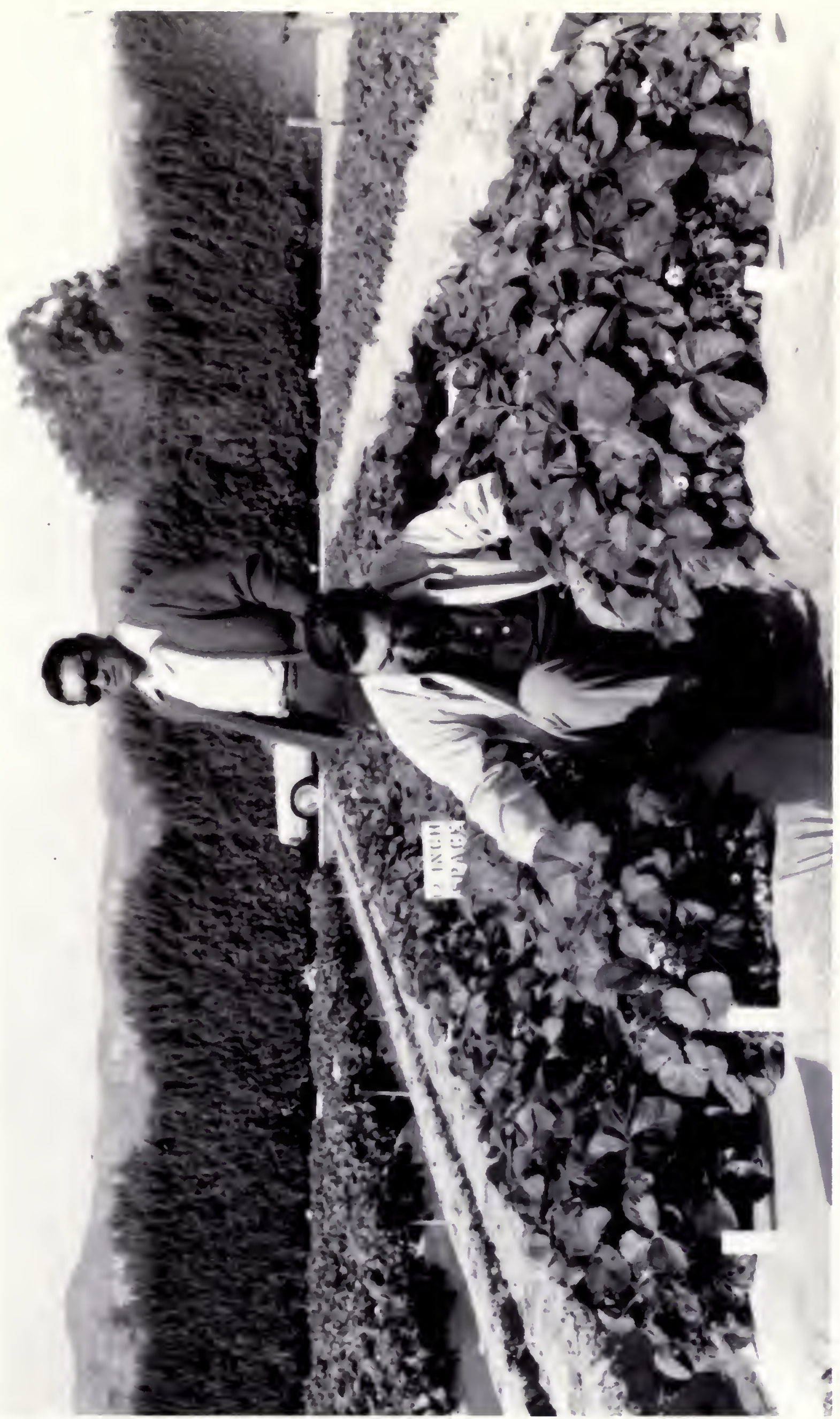

them for a hiyher price fresh don't you?

Shikuma: Well ... yes, we do. We expect to get a little more money from the fresh berries, but then it isn't necessarily so. It all depends on the demand of the frozen berries, too. Laborwise, the pickers would prefer to pick fresh berries rather than the frozen berries.

Jarrell: Why?

Shikuma: Well they have this incentive for picking fresh berries. I don't know whether they feel better picking fresh or what, but they prefer it. You have to stem berries for the freezer. You have to stem then and it's a little more tedious, too.

Jarrell: Yes.

Shikuma: Whereas with the fresh berry, you just kind of flick the stem off.

Jarre11: Do you mean that for the frozen food plant, the berries are stemmed by hand?

Shikuma: All have to be ... yes.

Jarrell: Is it just like if I'm in my kitchen getting them ready for dessert and I'm taking the stems out?

Shikuma: Yes.

Jarrell: W'here's no mechanized process for this?

Shikuma: iNo, there isn't.

Jarreli: Weil I'm surprised that strawberries don't cost a lot more than they do.

Shikuma: You have to ripen your fruits a little more to pick for the Erozen berries than you do for the market berries. 

Jarrell: I see.

Shikuma: Because if you try to stem them early, the berry is too hard. When it's too hard, they aren't going to stem. But when they get good and ripe, why the stem comes right out. It'll kind of stem itself without your having to work at it too much.

Jarrell: Do the field workers use little knives for the stemming or do they do it by hand?

Shikuma: By hand. But usually when we start going to the freezer, we just let the berries stay on the vine an extra three or four days so that the workers can just kind of puli them off the plant.

Jarrell: I read that by 1910 the Japanese produced $70 \%$ of the strawberries in California. Now much of the initial growth of this crop was in this area right here?

Shikuma: Yes.

Jarrell: It spread throughout the state into various agricultural areas ... is this correct?

Shikuma: Yes.

Jarrell: Plus we have Mexico now.

Shikuma: Yes.

Jarrell: How many acres of strawberries do you have?

Shikuma: This year I'm going to have a little over 70 acres.

Jarrell: How many did your father have in his earlier days? Let's say in the '20s.

Shikuma: well $\ldots$

Jarrel1: Do you have just a rough idea? 
Shikuma: Yes. I think he had around 20 acres.

Jarrell: So you have roughly three times as much?

Shikuma: Yes.

Jarrell: Could you tell me generally what has been the trend here over the years then with regard to the size of what we could call a small family farm? I don't know how large a small family farm in strawberries would be.

Shikuma: Well, the small family farms I would say right now are on a scale of 8 to 15 acres.

Jarrell: Versus the larger acreages requiring a number of hired workers which is what you do?

Shikuma: Yes.

Jarrell: Woula you say that people, growers like yourself, predominate in the valley in acreage?

Shikuma: Well, in terms of acreage, I don't know how you would term the Driscoll's with the sharecroppers. would you place them in the same category as I am?

Jarrell: Well I guess it's definitely changed. Sharecropping and commercial growing are the two categories that seem to predominate in the valley here.

Shikuma: Yes.

Jarrell: There don't seem to be just family units with a few hired people in strawberry farming.

Shikuma: Actually there are quite a few Japanese growers and a few Mexican families.

Marketing

Jarrel1: What do you do with your berries when they're 


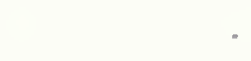


harvested here? Where do you take them?

Shikuma: I take them to Naturipe.

Jarrell: Which is a packing shed?

Shikuma: No. We receive at the apple growers cold storage here. They have the precooling facilities; we rent the precooling facilities or we pay for the facilities. The berries are received there and shipped from there ... all from one place.

Jarrell: Did your father in his days, let's say in the '20s, pack berries in little wooden boxes?

Shikuma: Well what he originally started doing, as I recall, was to put the berries into little trays.

Jarrell: Made out of wood?

Shikuma: Yes, wood. And then they went into what we called a chest. Each chest, if you went on this particular crate size, would carry 8 , and if you went to what we call the slide size, the crate would carry 16. And then they would all be slid into this chest and the lid would be closed and a screw would hold the lid and it would be hauled in this manner. Later they would have to truck the chest back.

Jarrell: Oh, I see. They were recycled?

Shikuma: That's right. But the crates were not.

Jarrell: Just the chests?

Shikuma: Yes, just the chests.

Jarrell: So these kept the berries cool and fresh in transit?

Shikuma: Well, that was just a container to ship the strawberries in. Like when we went into the Los Angeles market, the freight car would have ice bunkers, but 

going into San Francisco the berries would be just shipped in old truck beds, or whatever you call them.

Marketing -- Cooperatives

Jarrell: Could you talk a little bit about the marketing procedures; the distribution, sales, particular markets; and how they have changed since the '20s?

Shikuma: Well, of course my dad originally started marketing and getting financed by the local commission merchants. And then I think his uncle, and then my dad right shortly after that, was instrumental in starting this marketing club called the Central Valley California Berry Growers Association which today is Naturipe.*

Jarrell: Now what year would this be that Naturipe or the Central California Berry Growers Association ... what year was this cooperative established?

Shikuma: Gosh, I don't know just what year it was established. I think my brother has the date in his book.

Jarrell: Oh, I can look in there. I might have missed it, yes. Do you know any of the other families who were involved in the formation of the cooperative? or was this your father's idea?

Shikuma: No. He wasn't the original director. I think he was probably instrumental in it, but he wasn't one of the younger Isseis at the time when it was formed. I think my dad's uncle, Kotaro Shikuma, was one of the original directors. And then a year or two later my dad became a director. He was director for years and years and years.

Jarrell: What area did this take in? I know it's in Santa clara county today ... was it the same areas in the past?

${ }^{\star} \mathrm{Ed}$. Note:

The first meeting of the Central California Berry Growers Association was held in San Erancisco on April 9, 1917. In J958 the organization adopted the name Naturipe Berry Growers, and is presently the largest strawberry cooperative in the country. (wilhelm, stephen and Sagen, James E., A History of the Strawberry: From Ancient Gardens to Modern Markets,

Berkeley: Agricultural Publications, University of California, 1974, p. 194; 208.) 

Shikuma: It took in Watsonville and the Santa Clara Valley, I think.

Jarrell: Monterey also?

Shikuma: I think there might have been a little out on the tip of it. The main office was in San Francisco.

Jarrell: Now can you describe this cooperative? It was the growers getting together for distribution purposes ... to expedite distribution ... is this correct?

Shikuma: well, we still shipped into the market that mountain members shipped into, even though we were in a cooperative. The cooperative kina of went into the market to see that each farmer was given a fair market price. It was just sort of a protection for the member growers. And then later I think they started a little interstate shipment. In the fall they would start shipping a few berries into the Eastern market.

Jarrell: And these would go by rail?

Shikuma: Yes, they would go by rail.

My brother, Kenji, went to work for the cooperative after he graduated from stanford. His job during the regular season was to go to San Francisco and Oakland and check on the market and see how many of the grower member's berries were on the market. He checked on the price they received.

Jarrell: Kind of gauging the market?

Shikuma: Yes. And making sure that they were receiving the equivalent of what others were receiving or at least the fair market price. Later the co-op started a Los Angeles shipment. We would have a man here helping the growers get the cax and then shipping it into the Los Angeles market. They would keep a record of just who was shipping and how many crates 



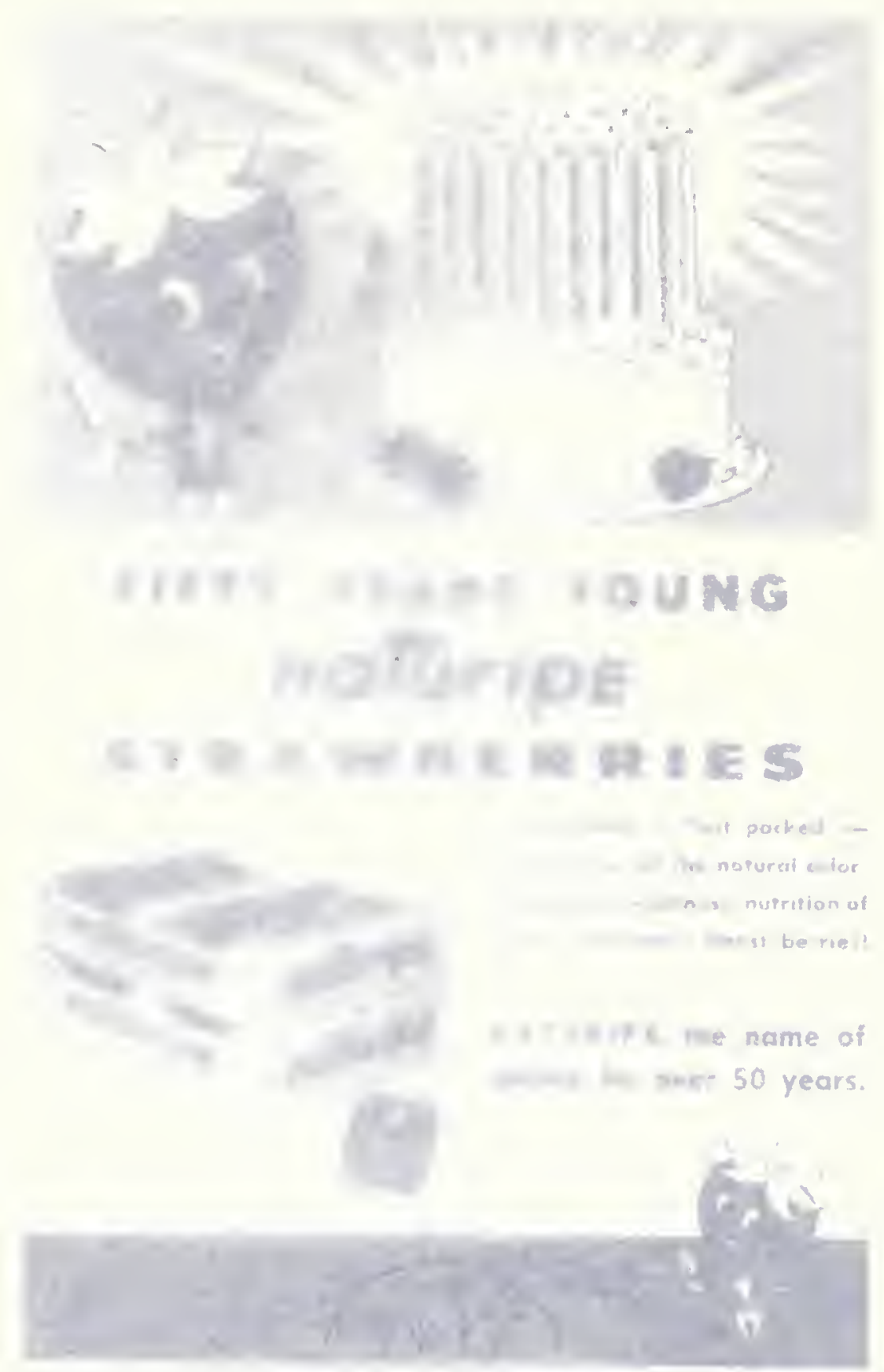

NATURIPE BERRY GROWERS

(Advertising poster) 
$\sigma\lceil\varepsilon$

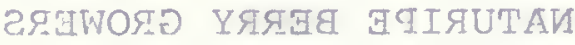

( x9J2oq priaify9v5A) 


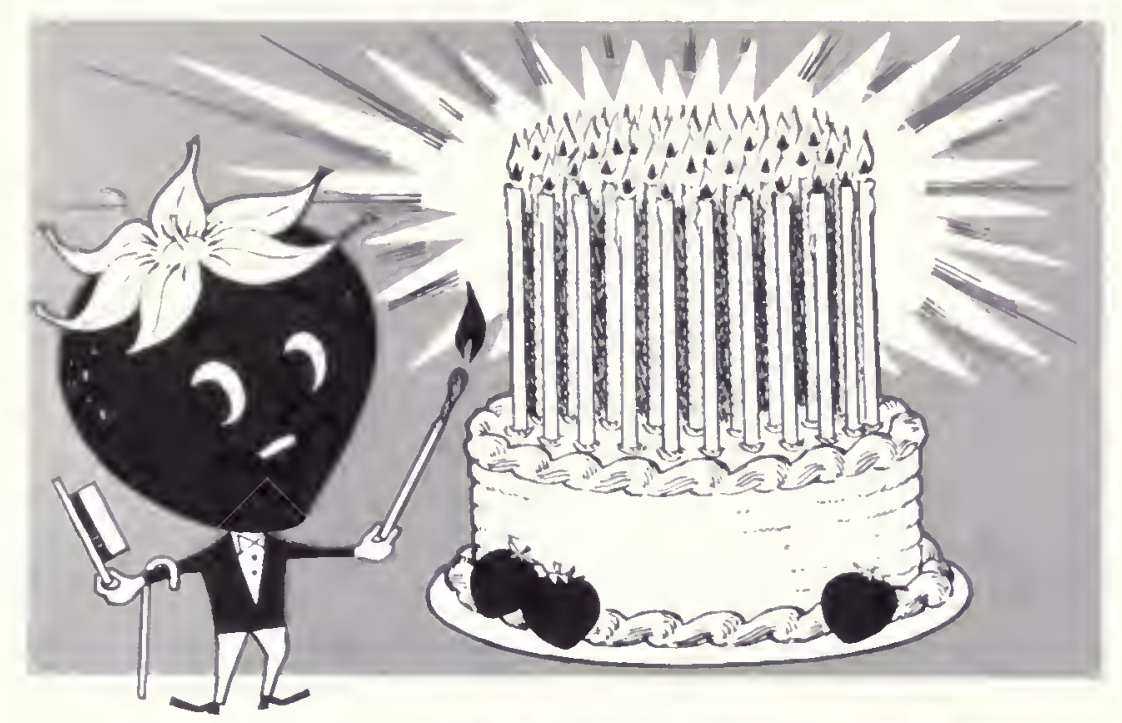

\section{FIFTY YEARS YOUNG naturipe \\ STRAWBERRIES}

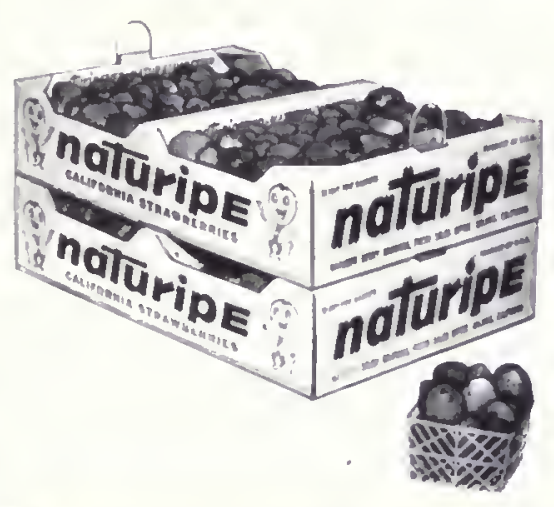

Fresh picked - fast packed to bring you all the nafural color, plumpness, sweetness, nutrition of sunny California's finest berries 1

NATURIPE, the name of quality for over 50 years.

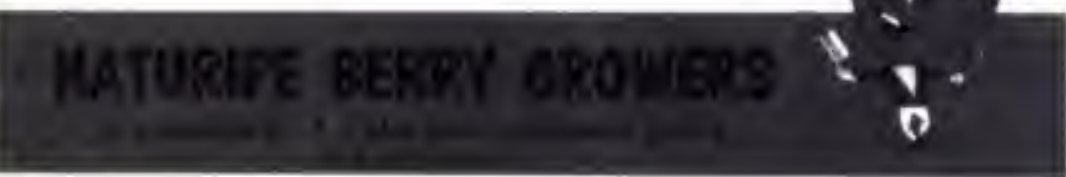



and what kind of ... then they would receive a telegram back from the market reporting the market price. And then from there ... I know kenji, in the fall when they eventually started the Eastern shipment, why my brother would go to the Eastern market. And as the strawberries would arrive, he would help distribute them into the different. markets in New York and into the other nearby Eastern markets. So that was kind of the start of the interstate marketing program.

Jarrell: But in the early days most of the berries from Pajaro Valley ended up in San Francisco?

Shikuma: Yes, the San Francisco market.

Jarrell: And then the next area would be Los Angeles?

Shikuma: Yes, Los Angeles.

Jaxrell: Now what about Seattle or Portland? Would strawberries from here go up there?

Shikuma: I don't know too much about that, but I think some did eventually get up into those markets by rail.

Jarre12: And then the market became interstate?

Shikuma: When I started strawberry farming in 1949, I was shipping strictly into the San Francisco and Los ingeles market. I uecame a member of the Central California Berry Growers Association.

Jarrell: Is it mostly a Japanese organization or of many different growers?

Shikuma: Wel], I think originally it was mainly a Japanese Grower's association, but during the war years, since no Japanese was growing strawberries ... well the Driscoll famil $\ddot{y}$ and the Reiter family were old strawberry-growing families, too. So they kind of expanded theix strawberry-growing venture, and I 
know when I came back, we had lost touch with the co-op. We called on Mr. Haack who was a manager before the war... I think the Driscoll and Reiter families kind of held the association together.*

Jarrell: During the relocation years?

Shikuma: Yes. During the war, the Driscoll people kind of developed their own varieties. They started to do this because Dr. Thalmus ... who was with the University of California, and has since left... went with the Driscoll people. I think the University of California kind of gave up on this strawberry. Thalmus was instrumental in developing their z-5-a's, and what they call the Driscoll berries. When we came back, we all joined the Central California Berry Growers Association again. Not all of us joined. A few of us who were old-time member families decided that the central California Berry Growers Association would have our shipping program while the Driscoll people had theirs. There was some understanding why they agreed to separate from us. They continued on with their Driscoll shipping venture and we continued with Naturipe.

Jarrel1: Is Naturipe a brand name, also?

Shikuma: It is.

Jarrell: When you have a box filled with cartons of berries, does it say Naturipe on the outside?

Shikuma: Yes.

Jarrell: Which means that the berries came from one of the growers in the Central California Berry Growers Association?

Shikuma: That's right.

Jarrell: Would you say that the Naturipe berry has a high reputation?

*Ed. Note:

For a history of the Naturipe organization see Wilhelm and Sagen, A History of the Strawberry (1974), op. cit. 
Shikuma: Well we think it has.

Jarrell: Do you know anything about the Watsonville strawberry co-op? Is it Mexican-owned and run?

Shikuma: No. It's Mexican and Japanese. Mexicans are the minority. I think they have about 5 or 6 Mexican growers and the balance of I would say about 20 or 22 would be Japanese growers.

Marketing -- Supply, Demand, and Promotion

Jarrell: What do you think, looking back over the years, are the main reasons for the very sharp fluctuations or changes in the berry crops in the Pajaro Valley? Now we know that there was moderate acreage before the war, then it dropped to zero during relocation, and then after the war it expanded very sharply when, in 1956, there were about 3000 acres planted here in the valley.

Shikuma: Yes.

Jarrell: Now since 1956, I think acreage has gone below 3000 acres. What do you think accounts for this?

Shikuma: Well, you know, when I started in '49, I planted... there were a few who started a little earlier ... but there being a scarcity of berries, the market was very good. It's just supply and demand that prompted the acreage fluctuations. I know when I started we were getting... well $\$ 4$ was not unusual on a weekend market, you know.

Jarrell: That $\$ 4$ refers to ...

Shikuma: $\quad \$ 4$ per tray.

Jarre].1: I see.

Shikuma: So people would plant more when the buyers said 

give us more berries. We were led to believe that there was no saturation point.

Jarrell: You could just keep going infinitely?

Shikuma: Just keep going, yes. The strawberry was really a desired item and we thought that we couldn't possibly overproduce. So this prompted business people and doctors and other professional peoples to invest money in the strawberry market.

Jarrell: I see.

Shikuma: They would finance growers; they would put up the money. This encouraged a lot of people, including a lot of my race of people, to come from Los Angeles and from the cities. They heard that you could make a mint raising strawberries.

Jarrell: It was a get-rich-quick sort of thing.

Shikuma: Yes, and capital was easily available because all these people were interested in investing in a strawberry crop.

Jarrell: What years are you talking about when this sort of boom thing was on?

Shikuma:

Well I would say around 1952, '53, '54. Then we saw the crash come in 1957. All of a sudden we were told that we had an oversupply of freezer berries at $8 \&$ a pound. We also had an oversupply of fresh berries at $\$ 1.50$ a crate. I experienced that I couldn't repay my loans. I had to mortgage what I had with the bank. And those crops that were financed by people who didn't have any land or any holdings to mortgage ... why they just went bust. So when the acreage went down, why the strawberry market came back again. Right now the consumption varies with our niarketing orders and with our advertising and our promotion. The consumption has increased greatly, too. 

Jarrell: Is this one of the areas that Naturipe works in? Isn't there a Strawberry Advisory Board?

Shikuma: Well we're part of the Strawberry Advisory Board and we contribute to the Strawberry Advisory Board.

Jarrell: You contribute information about the specific yields, et cetera?

Shikuma: Yes. And the Strawberry Advisory Board does all the promotional work.

Jarrell: How is the Strawberry Advisory Board financed?

Shikuma: By an assessment.

Jarrell: An assessment of the growers' yield?

Shikuma: The growers are assessed so much and the shippers are assessed so much a crate.

\section{Labor}

Jarrell: I've read that your father imported young Japanese workers to work in the strawberry fields. What year was this in?

Shikuma: Well, he did this in '55 and '56, I believe.

Jarrell: Is this still done today to any extent?

Shikuma: I don't think so. These boys came under the Refugee Relief Act.*

Jarrell: I see.

*Ea. Note: The Refligee Relief Act of 2953 authorized the issuance of special non-quota immigrant visas in specified numbers to certain groups of aliens seeking to enter the United States as imigrants. 

Shikuma: These were boys who were supposedly displaced Japanese youngsters and I think most of them were ex-servicemen. They were in China, or Korea, or Manchuria during the war years. After the war they were sent back to Japan. They had no place to go in Japan, or didn't have anything to do, so they were able to qualify for this Refugee Relief nct program.

Jarrell: Do you think your father could have maintained his level of production without those young men?

Shikuma: I personally think so. At that time I was mainly sharecropping, and then when my dad said that he would like to help these boys out, why that's when I went commercially on my own and started using these boys in a commercial program.

Jarrell: Now you were sharecropping?

Shikuma: Yes, I just continued what my father was doing when I went into strawberries. I got four Japanese families and gave each one three acres of strawberries. I provided the land and the plants, fertilizer, spray, the capital and the tractors. They did the cultural work and then we went 50/50. I marketed the berries for them. I hauled the berries into town. My first experience with commercial growing on my own, which I do now .... I have no sharecroppers now.

Jarrell: Is sharecropping still a common method of farming strawberries?

Shikuma: Very much so.

Jarrell: In California agriculture, generally, sharecropping is a rarity.

Shikuma: Yes.

Jarrell: In terms of other crops even. 



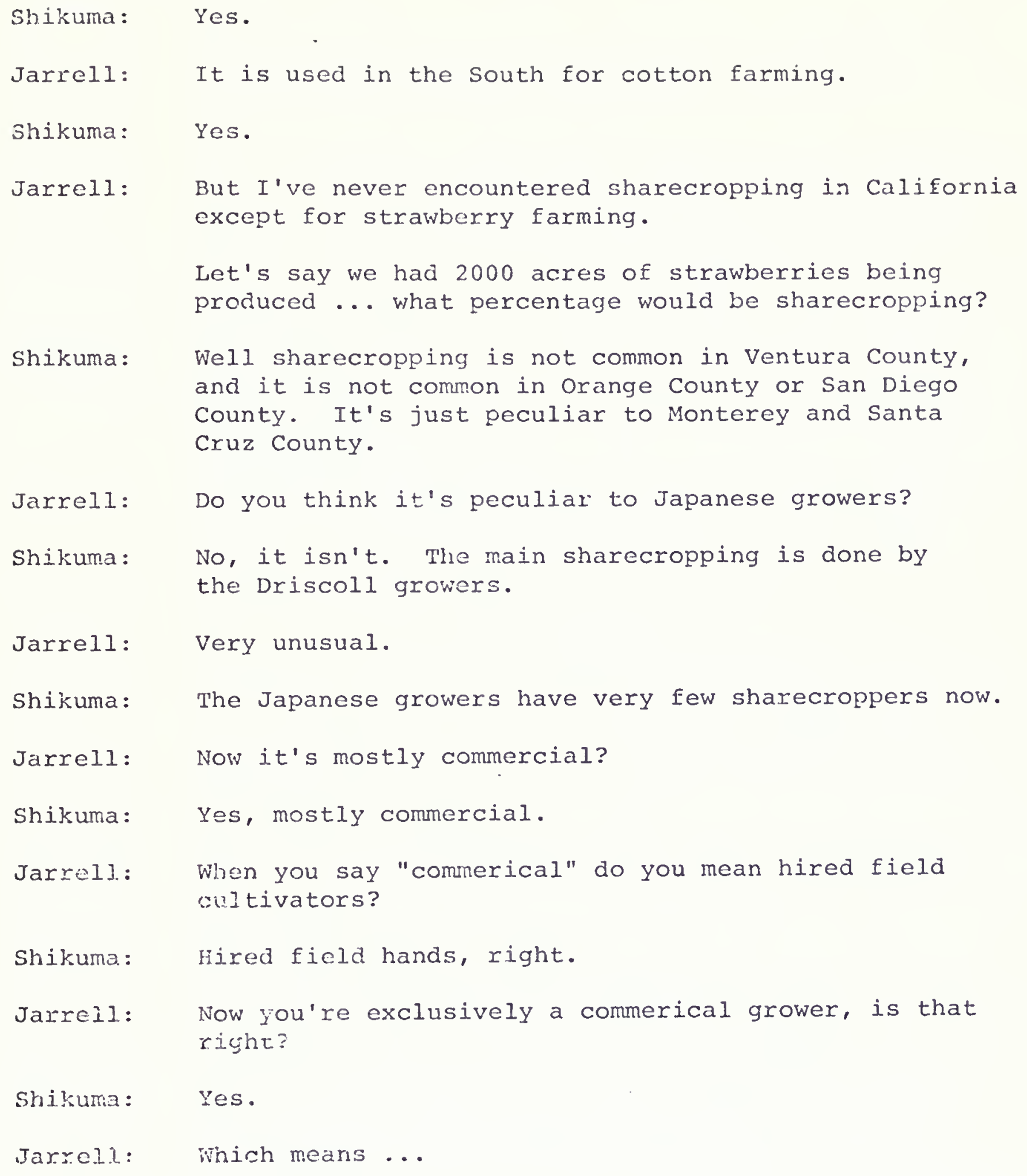



Shikuma:

Jarre11:

Shikuma:
That I hire all my labor to raise all my crops.

If you had 70 acres, can you kind of give me a breakdown of the labor involved?

Well, right now, * you know, with this weather the way it is, we work infrequently. But I still maintain about 20 boys. And when I get into my full harvest season, I need about 2 to $21 / 2$ men per acre. If we were using the old method of farming where we farmed double row and all that, maybe 3 men per acre would not suffice, but since we go ... I'm mostly in annual planting now and that's because of the reduced need for labor and what the labor can do for me. With the single row planting and with the annual planting my plants don't get quite as bushy, and pickers can pick more, they make more money, and I can get by with less labor. I still need, oh, from 2 to $21 / 2$ men during my peak harvest. But that's just over a short period of the time, then it falls again.

Jarrell: How long is your peak harvest?

Shikuma: It occurs probably from May to early June.

Jarrell: So you're hiring for say six weeks. Would that be accuxate?

Shikuma: Well, about a six-week period, yes.

Jarrell: Then you'd have roughly a 150 men?

Shikuma: Roughly.

Jarrell: Now, where do you get these men?

Shikuna: They're mostly green-card Mexican workers.

Jarrell: Now does that mean that they're Mexican nationals who come here for seasonal work?

*March 11, 1975 
Shikuma: Yes.

Jarrell: If you didn't have the green-card workers, could you make it?

Shikuma: $\quad$ No, I couldn't.

Jarrell: You wouldn't have the people?

Shikuma: Right, I wouldn't have enough people.

Jarrell: That's interesting.

Shikuma: I went through this particular experience when they eliminated the bracero program.* I immediately cut my acreage down because I didn't know where my source of labor would be. But with the acreage I did have, we recruited and sent a bus into San Jose because we were told that there was labor available there.

Jarrell: Was this among the Mexicans in San Jose?

Shikuma: No. In general. I had Caucasians and Mexicans come from San Jose and we bussed them here to Watsonville. And of course, you know, the cost of busing them here was prohibitive. And then on top of the busing problem a lot of these people were here just for experience's sake.

Jarrell: They didn't know what was involved in cultivating strawberries?

Shikuma: They didn't know. And of course I couldn't condemn them, but then I had secretaries and I had college kids and truck drivers and just... you name them, I had everyone. When you're unaccustomed to this type

*Ed. Note: In 1951 congress enacted Public Law 78 in response to labor shortages during the Korean War. P. L. 78, also known as the bracero program, governed the temporary importation of Mexican workers, and was extended annually until 1964. 

Jarrell:

Shikuma:

Jarrell:

Shikuma:

Jarre11:

Shikuma: Right.

Jarrell: Can you pinpoint for me at what point the labor supply of this area ceased to be adequate for the work. and the production that were to be done, and when you started having to use people from outside this area?

Shikuma: Well, right now for my own needs, there's adequate labor available locally.

Jarrell: Really?

Shikuma: Well, the people that are working for me now are local people.

Jarrell: They live here?

Shikuna: Yes, they live here. The migrant workers know when the season starts and they come just about at the 

point when the domand requires them. In this area we start to require this migrant labor force toward the middle of April. There are some that come from Texas.

Jarrell: All the way to here?

Shikuma: Yes. They migrate here from Texas. But my feeling is that we have less and less of the Texas, Arizona workers. Those who come from Texas and Arizona that can speak English are finding more work in the canneries and freezer plants and less are doing field work.

\section{Unions}

Jarrell: Can you recount for me a little bit about any experiences you may have had with union organizers among field workers in the valley here from the time you got into berries in 1949 to the present?

Shikuma: Well, my first experience with this was in 1970 when the UFi [United Farm Workers], or [Cesar] Chavez's union, began to organize. They started talking to the field workers. Since then the Teamsters have entered into the picture, too.

Jarrell: I see.

Shikuna: I was approached by the Teamsters two years ago. They were going to organize my workers. I don't know for what reasons they didn't organize, or carry their intentions any further. The other union, Chavez's union, works a little differently. They don't approach a farmer; they work with the Jaborers first without approaching us or informing us that they are going to organize. As a result, we had this big strike in 1970 where we had a complete walkout. Then we went into negotiations.

Jarrell: Now "we" would be all of the growers? 
Shikuma:

We11, originally we started as a group of Naturipe growers; then all the other growers joined us, and then we were represented by one negotiator and the Driscol.1 growers and the independent growers and the Watsonville Berry Co-op Berry Growers. We all joined forces and of course the representative from each group attended these negotiation sessions. But we couldn't agree on terms and we terminated our negotiations.

Jarrell: And this was with the UFW?

Shikuma: Yes. And since then we haven't negotiated or done anything like that. The following year after we terminated the negotiations, Chavez's group was around our fields quite frequently with their bullhorns telling our workers to walk out. They said the farmers were no good and that the workers should go with the labor organizers and they'd give them a better deal and all that. But for some reason my workers didn't leave me; they stayed with me and they harvested all my crop, and we haven't had a walkout since.

Jarre11: Now this was during 1970 and here we are five years later.

Sinikuma: Yes.

Jarre11: Is there an established field workers' union in the valley now?

Shikuma: Yes, there is.

Jasel. 1: There is?

Shikuma: I think that the majority of the lettuce farmers are with the Teamsters Union.

Jarre.1.: Yes, that's right. But in strawberries?

Sinikuma: In strawberries, no. The only strawberry grower 

with a Teamster contract is Tomasello Company. Of course he is a vegetable grower and a row-crop farmer. It was only natural that he go with the Teamsters.

Jarrell: Do you recall any organizing efforts in the '20s and ' 30 s?

Shikuma: Well yes, but they were kind of before my time.

Jarrell: Did your father have union field workers?

Shikuma: No. They were all sharecroppers; just family units.

Jarrell: So he always consistently had shărecroppers?

Shikuma: Right. He was never a commercial grower. Except my dad always had a litt]e family farm for my brothers and sisters and my mother to tend to.

Jarrell: Thank you very much, Mr. Shikuma. I have enjoyed our talk, and I think your manuscript will be very informative for researchers. 

Trans: Doris Johnson

Typed: Doris Johnson 
INDEX

Bracero Program, 39-40

Central California Berry Growers Association, 30-33

(see also Naturipe Berry Growers)

Discrimination, 9-11

Driscoll family, 32-33

Driscoll Strawberry Associates, Inc., 18, 22, 24-25, 33, 38

Education, 7-8

Farms, acreages of, $12,27-28,34$

Food, 6

Haack, Ernst H. , 33

Housing, 5

Japanese, Passim

Land, alien rights, 8-9

Naturipe Berry Growers, 29, 30-32, 33-34, 36

(see also Central California Berry Growers Association)

Refugee Relief Act, 1953, 36-37

Reiter family, 32-33

Religion, 7

Relocation Centers, 10-11

Shikuma, Hiroshi, Passim

Shikuma, Kenji, 3, 18, 31-32

Shikuma, Kotaro, 1, 30

Shikuma, Unosuke, 1-3, 7, 9, 13-15, 30, 36-37, 44

Shikuma, Mrs. Unosuke (nee Haru Maenaga), 3-4, 5, 7

Shopping, 6

Strawberries

cultivating, 8, 15-16, 17-18

diseases, $17,18-23$

harvesting, 24, 39

labor, 36-44

marketing, 28-36

migrant workers, 41-42

mulching, 23-25

packing, 29-30

sharecropping, 12, 13-14, 37-38

transporting, 11-12, 29-30, 31

Strawberry Advisory Board, 36 

Thalmus, 33

Tomasel 10 Company, 43-44

Unions, $42-44$

Watsonville Strawberry Co-op Berry Growers, 34 

Randall Jarrell was born in Los Angeles and lived in the San Francisco Baý Area until moving to Santa Cruz in 1970. She received her A.B. in History from San Francisco State University in 1969 and an M.A. in History from the University of California, Santa Cruz, in 1978. She worked as a journalist before her appointment in 1974 as director of the Regional History Project.

Doris Johnson was born in Terre Haute, Indiana, and moved to the Santa Cruz area in 1965. She started work with the Regional History Project in 1967 as a senior typist clerk. Since 1976 she has been the editorial assistant for the Project. 







U. C. BERKELEY LIBRARIES 
